\title{
STRATIGRAPHY, GEOCHEMISTRY AND GEOCHRONOLOGY OF A QUATERNARY PYROCLASTIC SEQUENCE OF THE CHICHONTEPEC VOLCANO, EL SALVADOR
}

\author{
A. Aiuppa1, S.G. Rotolo ${ }^{1 *} \&$ I.M. Villa ${ }^{2}$ \\ (1) Università di Palermo. Dipartimento di Chimica e Fisica della Terra (CFTA) - \\ Via Archirafi 36 - 90123 Palermo, Italy \\ (2) Isotopengeologie - Erlachstrasse 9a - 3012 Bern, Switzerland \\ (*) Corresponding Author. E-mail: silrot@cfta.math.unipa.it
}

(Recibido 4/1/1999; Aceptado 27/5/1999)

\begin{abstract}
In this paper we present sedimentological, chemical and geochronological data on a pyroclastic sequence deposited at Chichontepeque Volcano (El Salvador) during a caldera-forming Plinian phase. Granulometric analyses and width distribution patterns of airfall pyroclastics showed that these are the result of at least two eruptions, the oldest being the more complete. The Basal Fall, which marks the beginning of the Plinian eruption, shows the typical features of Plinian air-fall deposits.

Chemical trends mirror roughly a downward tapping from a zoned magma chamber; inside each fall unit crystal fractionation trends can be recognized. ${ }^{39} \mathrm{Ar} / 40 \mathrm{Ar}$ dating of lavas underlying and overlying the pyroclastic sequence show that the Plinian phase occurred between $0.59 \pm 0.09$ and $0.55 \pm 0.04$ Ma before present.
\end{abstract}

RESUMEN: Se presentan datos sedimentológicos, geoquímicos y geocronológicos de una secuencia piroclástica originada durante una fase pliniana relacionada con la formación de una caldera en el volcán Chichontepeque (El Salvador). Los análisis granulométricos y la distribución de los espesores de los piroclastos de caida indican que se trata de por lo menos dos erupciones, siendo la primera más violenta. El horizonte basal marca el comienzo de la erupción pliniana y presenta las características típicas de un depósito de caida del tipo pliniano. Las variaciones geoquímicas indican que las diferentes unidades provienen probablemente de diferentes niveles de una cámara magmática zonificada y dentro de cada capa de caida se reconocen tendencias provocadas por una cristalización fraccionada. Dataciones ${ }^{39} \mathrm{Ar} / 40 \mathrm{Ar}$ de lavas que subyacen y sobreyacen la secuencia piroclástica indican que esta fase pliniana ocurrió entre $0,59 \pm 0,09$ y $0,55 \pm 0,04 \mathrm{Ma}$.

\section{INTRODUCTION}

Volcanism in El Salvador is nowadays located mostly around and inside a regional tensional structure, the so-called Central Graben, that runs for several hundred kilometers roughly parallel to the pacific coast. Chichontepec is a composite volcano lying on the southern margin of the Central Graben. Its early activity was characterized by tholeiitic to transitional lava flows that changed to calc-alkaline through a calderaforming Plinian episode. 
This paper focusses on the pyroclastic sequence that was produced by this Plinian phase. We present granulometric data and whole rock chemical analyses, as well as three $39 \mathrm{Ar} / 40 \mathrm{Ar}$ ages.

\section{GEOLOGIC FRAMEWORK}

Chichontepec, also known as "Volcan de San Vicente", is the second largest volcano of El Salvador for the volume of emitted products (130 $\left.\mathrm{km}^{3}\right)$, after Santa Ana volcano $\left(165 \mathrm{~km}^{3}\right.$, Carr et al., 1981). It is located approximately $50 \mathrm{~km}$ east of the capital city, San Salvador; the city of San Vicente lies on its northeastern slopes. Chichontepec is a densely vegetated paired stratovolcano with summit craters aligned in an E-W direction. Based on morphology, the most recent crater is the easternmost (elevation $2180 \mathrm{~m}$ ), while the western crater (elevation $2105 \mathrm{~m}$ ) appears to be older (Fig. 1) . There is no evidence of historical eruptions, its youngest products being covered by the AD 260 Tierra Blanca tephra emitted from the nearby Ilopango volcano (Hart \& Steen-McIntyre, 1983).

The edifice rises inside the Central Graben structural depression, a late-Pliocene extensional structure (20 to $30 \mathrm{~km}$ wide) that runs along the length of El Salvador in a WNW-ESE direction. The graben cuts through a Tertiary volcanic basement which locally consists of basalt and andesite lavas, tuffs, agglomerates, and lacustrine diatomite deposits (Williams \& Meyer-Abich, 1955; Pichler \& Weyl, 1973; Wiesemann, 1975; Carr, 1976; Carr \& Stoiber, 1977; Carr et al., 1981). All recent volcanoes in El Salvador are aligned along the axis of the graben .

Nowadays Chichontepec volcano is characterized by a solfatara-type activity. Low temperature fumaroles $\left(\mathrm{T}<100^{\circ} \mathrm{C}\right)$ and hot springs are located along faults breaking through the northern and western flanks of the volcano (Aiuppa et al., 1997). The summit craters do not present any fumarolic activity.

Previous studies have recognized a multistage evolution in the San Vicente volcanic area
(Barberi et al., 1995; Rotolo et al., 1998; Rotolo \& Castorina, 1998). The most important stages and events in the history of the volcano are:

\section{Stage 1: La Carbonera pre-caldera complex (CARB)}

The first stage is characterized by the effusive activity of an older volcanic centre, that hereafter will be referred to as La Carbonera volcanic complex (CARB). It produced mildly tholeiitic to transitional lavas, which range from high-alumina basalts to dacites.

\section{Stage 2: La Carbonera Plinian activity}

CARB effusive activity was interrupted by an explosive phase that led to the partial collapse of the edifice, whose remnants now form an annular structure (La Carbonera Caldera) of cinder cones and lava flows to the west of the Chichontepec edifice.

The pyroclastic deposits which were produced during La Carbonera Plinian phase are the objects of this study.

\section{Stage 3: Chichontepec post-caldera complex (CHI)}

The renewal of volcanic activity inside $\mathrm{La}$ Carbonera caldera after these paroxismal events led to the emission of a considerable volume $\left(130 \mathrm{~km}^{3}\right)$ of two-pyroxene andesites that built up the Chichontepec (CHI) edifice. Small volumes of block and ash pyroclastic flow deposits, interposed between andesitic lavas, are probably connected to low-volume dome collapse events. The lowest slopes of the volcano, particularly in the southern and western sector, are covered by lahar deposits; one small lahar occurred in the rainy season of 1995 . As a whole, the volcanic emission centres followed an eastward migration trend, roughly parallel to the Central Graben.

The studied area is characterized by several post-Pliocenic fault systems. The main sys- 


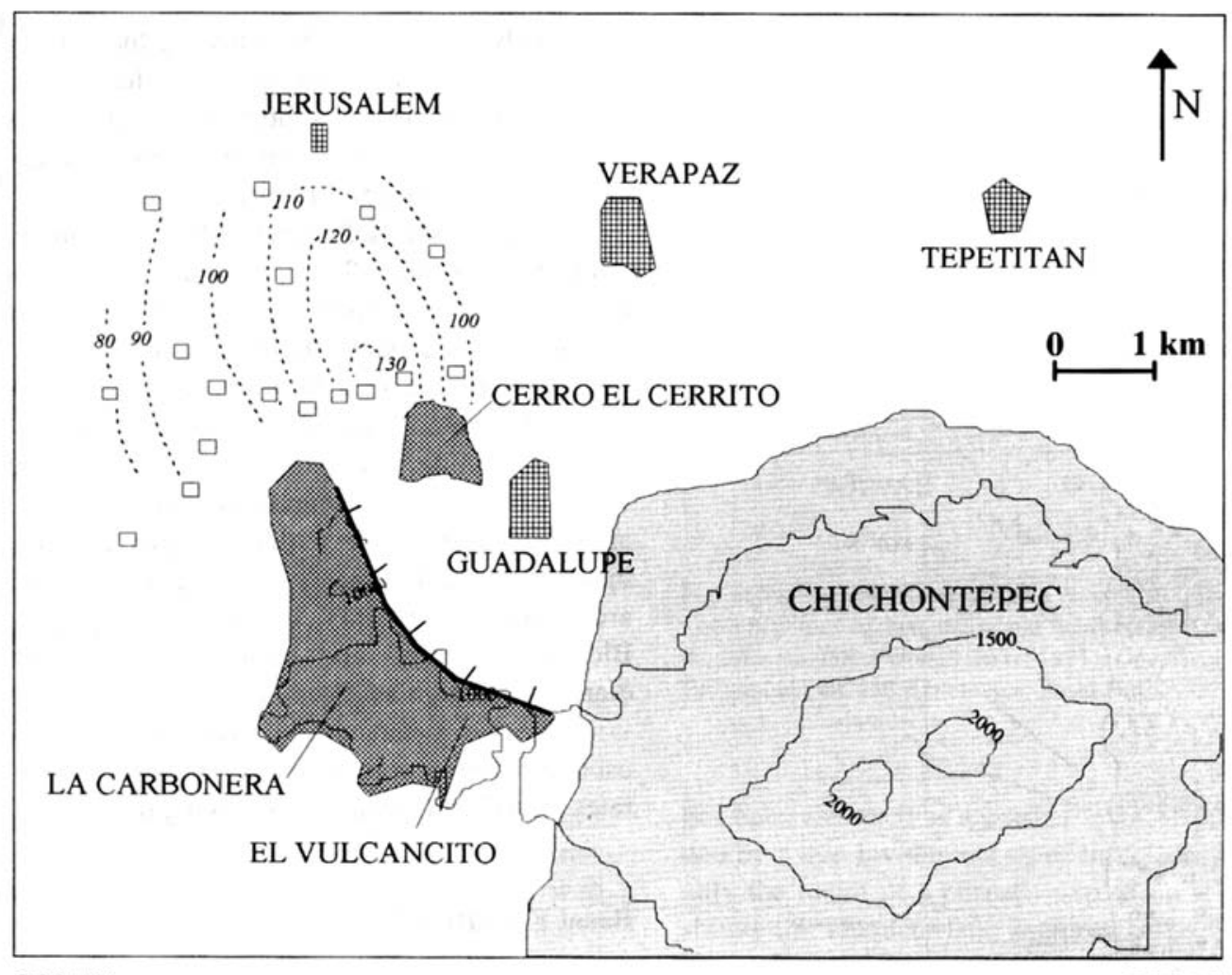

Fig. 1: Generalized map of the Chichontepec volcanic centre. Cross-hatched: pre-caldera lavas; grey-coloured: Hichontepec postcaldera lavas. Contour lines (dashed) represent the isopachs of the Basal Fall thickness; empty boxes are the measured stratigraphic sections.

tem is WNW-ESE trending and runs parallel to the Central Graben. It is offset by the younger annular fault system that borders La Carbonera remnants and witnesses its collapse. A radial fault system centered on Chichontepec is the youngest tectonic structure recognized.

\section{STRATIGRAPHY}

In this work we present data collected on 24 sections of tephra belonging to the pyroclastic sequence (stage 2). They are all located in the western part of the investigated area (Fig.1), around the annular remnants of La Carbonera caldera. In the south-western sector the sections found are heavily reworked by post-depositional processes, while in the easternmost sector of Chichontepec volcano we found no pyroclastic deposits correlated to those described here. A composite stratigraphic section is shown in figure 2. The whole sequence has been divided in 5 statigraphic units, which are described below from the bottom to the top.

\section{Basal Ignimbrite (BI)}

It is the oldest pyroclastic deposit in the area. It crops out south-east of the Chichontepec volcano, 

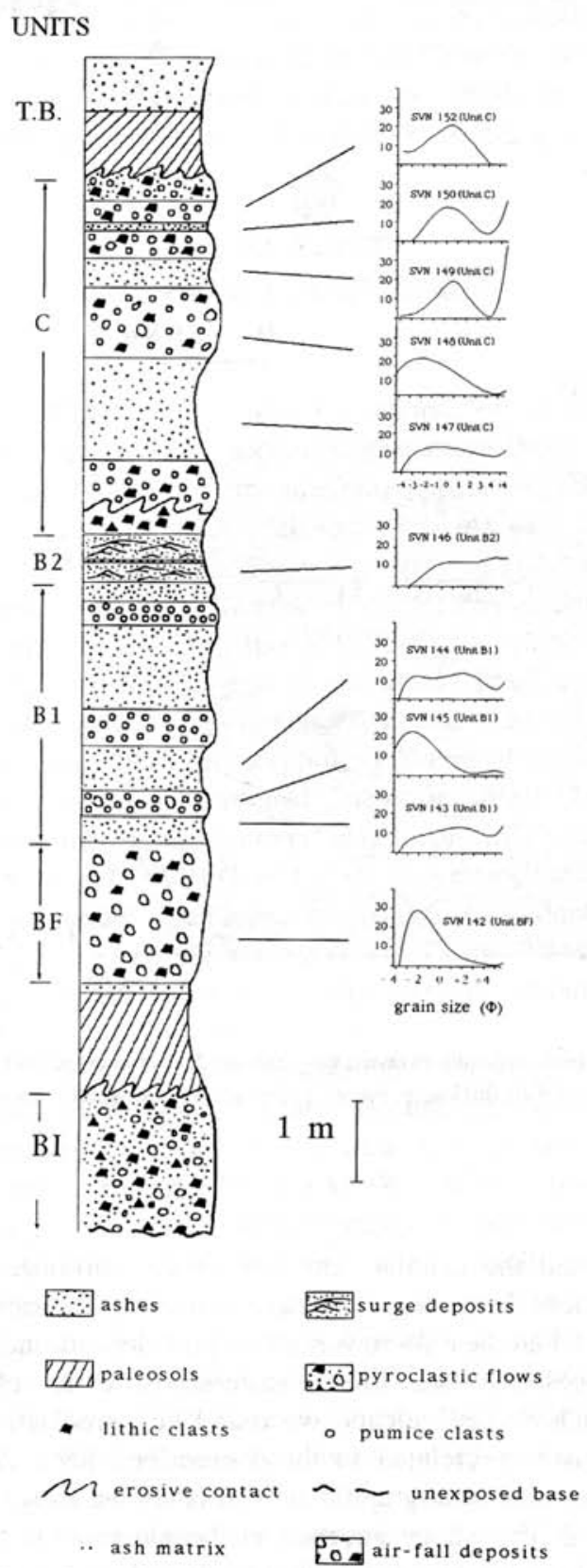

Fig. 2: Composite stratigraphic succession of the whole pyroclastic sequence. BI: basal ignimbrite unit; BF: basal fall unit; TB: Tierra Blanca.

Granulometric data are shown on the right. Granulometric analyses have been carried out by using a set of sieves with one-phi interval. Cumulative curves have been drawn by plotting cumulative weight percent against diameter (in phi units). particularly along the road connecting the town of San Vicente with the village of Zacatecoluca, $17 \mathrm{~km}$ SW of San Vicente. Its stratigraphic contact with the underlying CARB lavas is uncertain and badly exposed south of Cerro El Cerrito.

The Basal Ignimbrite, whose maximum thickness reaches $10 \mathrm{~m}$, is composed of an unsorted mix of pumice fragments (30 to $40 \mathrm{vol} \%$ ) and less abundant lithic lapilli (10 to 20 vol \%) and sparse crystals. All these components are set in a brown coloured ash matrix. Pumice fragments are white in colour, rounded and poorly vesiculated. Crystals (abundance 20 to $30 \mathrm{vol} \%$ ) are mostly plagioclase, with minor pyroxene and opaques. Lithic fragments are less abundant, and are composed mainly by altered andesites. Blocky pumiceous and lithic fragments, with diameters as high as $25 \mathrm{~cm}$ are also found.

A two meters thick brown colored paleosol, containing volcanoclastic fragments, separates the BI units from the overlying deposits.

\section{Basal Fall (BF)}

This is a dacitic fallout pumice deposit, indicating the onset of a Plinian phase. It is separated from the underlying paleosoil by a $10 \mathrm{~cm}$ thick level of fine grained (millimetric) layer composed of pumice and lithic fragments. Its thickness varies from 0.6 to $1.3 \mathrm{~m}$, and is mainly composed of pumice lapilli with lithic fragments (the pumice/lithics ratio is about 0.3). Pumice lapilli are rounded to sub-angular, white-grey coloured and highly vesiculated, with elongated subparallel vesicles. Lithic fragments vary from unaltered basaltic-andesitic rocks to completely recrystallized rocks in a phyllitic-propylitic facies.

This unit is relatively homogeneous. Gradation shows changes from reverse to direct. An upward increase in lithics relatively to pumice can also be observed.

Granulometric analyses, carried out on 14 samples, show a strong unimodal size distribution that plots with an S-shape in cumulative graphs (Fig. 3). The derived $\mathrm{Md}_{\phi}$ and $\mathrm{s}_{\phi}$ parameters (Inman, 1952) are those typical of fall deposits (Fig. 4). 


\section{Unit B1}

This unit is composed of numerous alternating coarse- to fine-grained beds, for a total thickness of about $2 \mathrm{~m}$. B1 beds lie in slight angular discordance onto BF deposits. The coarse-grained layers are composed of normally graded pumice fall deposits with minor lithics, while fine-grained beds are composed of brown coloured fine ash with no internal structures. The contacts between the alternating levels are in general sharp.

These features seem to be linked to the fluctuations in energy and height of the eruptive column. The instability of the column (i.e. the events of partial collapse) is recorded by brown ash levels containing pumice and lithic fragments (ash-flow pyroclastic deposits).

\section{Unit B2 (violet ashes)}

It is an ash-sized, grey to pinky-violet, pyroclastic surge deposit whose thickness ranges from 20 to $80 \mathrm{~cm}$. It is made of well-developed plane parallel beds whose thickness is about $10 \mathrm{~cm}$. The violet layer, which has been found in all the studied sections and therefore has been

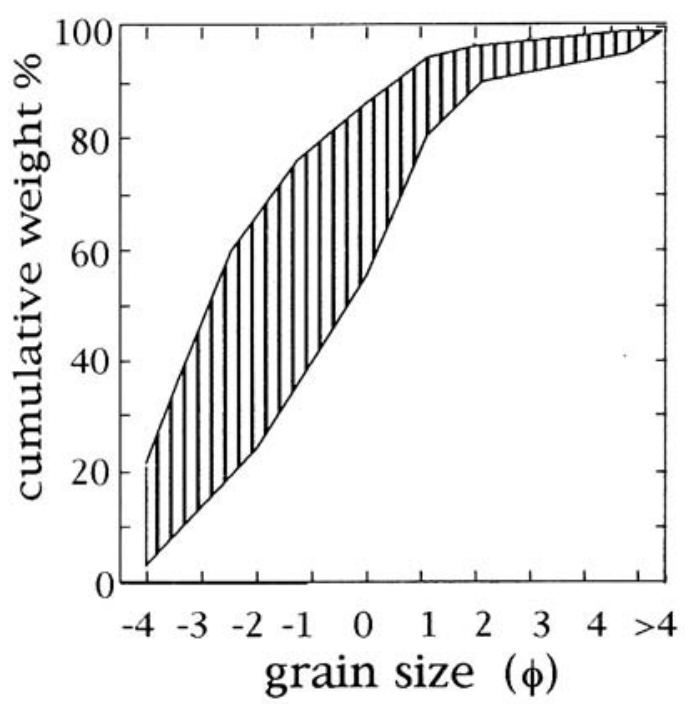

Fig. 3: Grain size vs. cumulative weight percentage for the Basal Fall. The hatched field shows the range of 14 granulometric analyses.

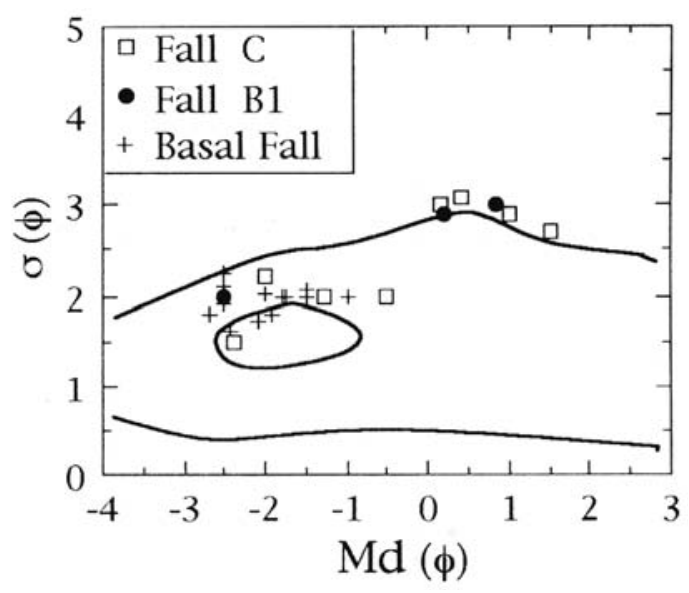

Fig. 4: Sorting $(\sigma \phi=(\phi 14-\phi 84) / 2)$ vs. median $(M d \phi=\phi 50)$. The solid lines enclose the whole field reported for fallout deposits (modified from Walker, 1971). Open squares: fall C; filled circles: fall B1; crosses: Basal Fall.

assumed as a marker level, is interbedded by a thin level made up of lithics only, probably the result of a phreatic explosion. The unit shows the characteristic features of hydromagmatic deposits, such as gas bubbles and accretionary lapilli (1-2 $\mathrm{mm}$ across).

Unit B2 probably refers to the the latest events of the eruption, during which magmawater interaction became possible.

\section{Unit C}

Unit B2 is cut by an erosion surface which, in turn, is overlain by a third pyroclastic unit (unit $\mathrm{C}$ ) belonging to a less complete eruption. Unit $\mathrm{C}$ is composed of alternating pumice and ash layers, very similar to unit B1; it ends with a paleosol, up to $2 \mathrm{~m}$ thick. The contact of Unit C with overlying post-caldera lavas is often badly exposed; one of the best outcrops is North of Cerro El Cerrito.

The whole sequence so far described is covered by a widespread wet-surge deposit known as "Tierra Blanca", which is made up of whitegrey ashes emitted from the paroxismal eruption that formed Lake Ilopango, in 260 AD. "Tierra Blanca" is thus the youngest deposit in the area. 

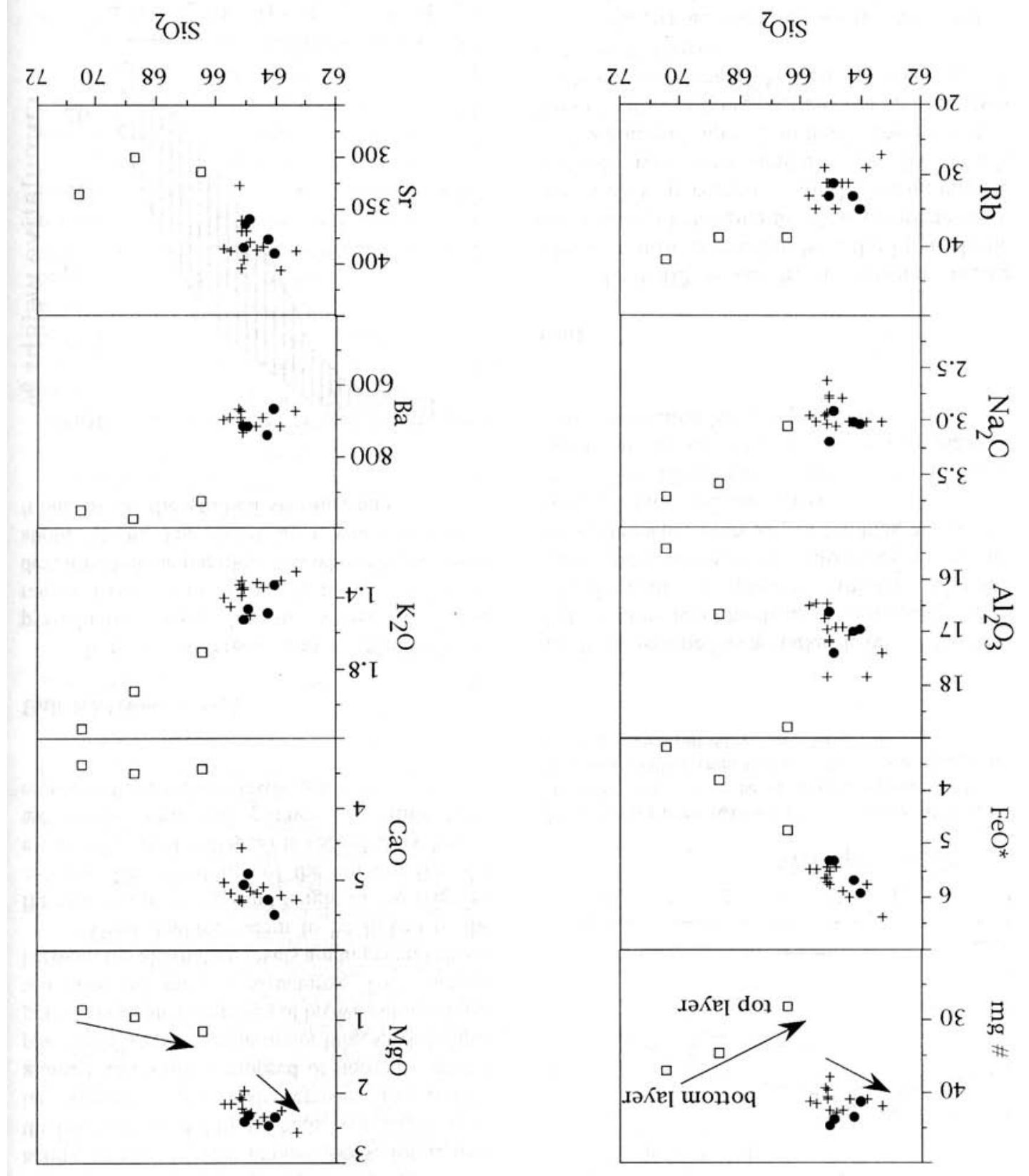

Fig. 5: Harker-type diagrams. Symbols as in Fig. 4. The arrows indicate the direction of younging inside each Unit (i.e. the higher stratigraphically level). Major elements are in wt. \%, minor in ppm. 


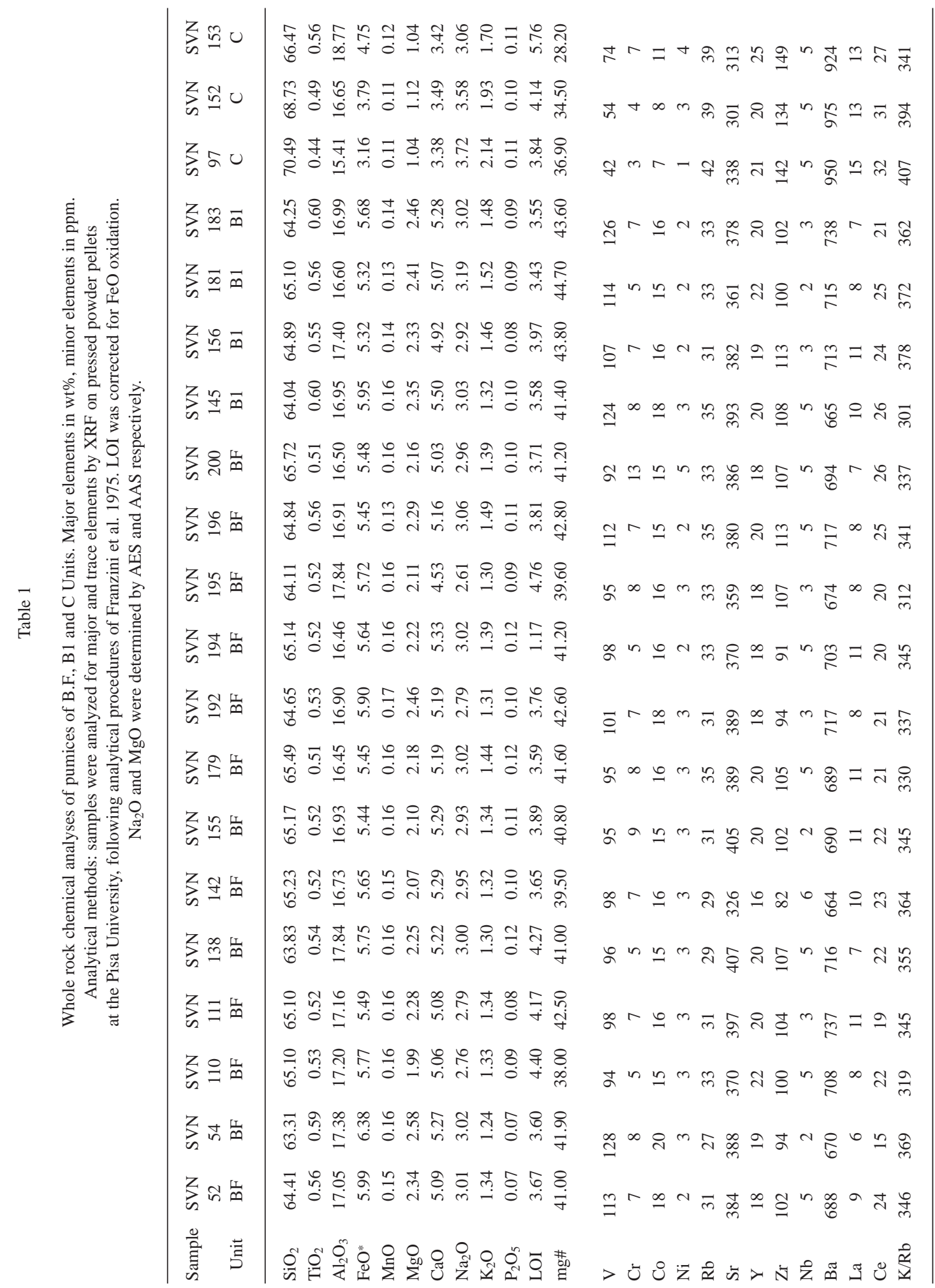




\section{AREAL DISTRIBUTION AND VENT LOCATION}

The isopach map (Fig. 1) drawn from measured thickness of Basal Fall unit (BF) is somewhat poorly defined due to the dishomogeneous distribution of the measured sections. In fact, in the north-western side of the map the outcrops are lacking or they are heavily reworked. Elsewhere (e.g. in the southern sector of La Carbonera) the lack of sections is due to recent avalanche and gravitative fluxes. In spite of these complexities, an elliptical distribution pattern with a NNE SSW axis, is recognizable. This direction is compatible with the direction of dominant winds blowing from the ocean. According to these data, the most probable position for the old eruptive vent should be inside the La Carbonera caldera. As a consequence, the Basal Fall should be related to the Plinian phases that led to the collapse of $\mathrm{La}$ Carbonera edifice itself.

\section{PETROGRAPHY AND GEOCHEMISTRY}

Whole-rock chemical analyses (Table 1) as well as petrographic observations have been carried out on pumice fragments collected from the three fall units previously described (i.e. BF, B1 and C). Broadly speaking, major elements show rough vertical variations inside each unit reflecting the time span from the beginning of each cycle. These features are clearly shown by the Harker diagrams (Fig. 5).

\section{Basal Fall Unit:}

The dominant pumice-type in the Basal Fall is white to light-grey, highly vesicular and slightly porphyritic: the total volume of the vesicles is as high as $60 \%$, while the porphyricity index is in the range $15-20 \%$. Phenocrysts are smaller than $2 \mathrm{~mm}$; among them a complexly zoned plagioclase is most abundant, followed by hornblende and pyroxene. The distinguishing feature of Basal Fall pumices is the occurrence of dark-green to brown hornblende (up to 5 vol \%), which is absent in other fallout layers. Hornblende is free of the opaque decomposition rim, which is instead common in overlying postcollapse lavas (Rotolo \& Castorina, 1998). Orthopyroxene and subordinate clinopyroxene are also present. Opaque minerals occur mostly as microlites even if some phenocrysts are also present. Sparse K-feldspar microlites begin to crystallize at a silica value higher than $64 \%$.

In the BF unit there is a clear decrease in silica and other evolutive parameters (e.g. mg\# ) from the bottom to the top: $\mathrm{SiO}_{2}$ ranges from 66 to $63 \mathrm{wt} \%$ respectively, while $\mathrm{MgO}$ variation is smaller, from 2.0 to 2.6. Fractionation vectors have been calculated for plagioclase, K-feldspar and hornblende. The $\mathrm{K} / \mathrm{Rb}$ vs. silica negative correlation reflects mainly the hornblende and plagioclase removal (Fig. 6), plus minor quantities of Kfeldspar $(<10 \%)$. The observed vertical variations could reflect the tapping of progressively less evolved (i.e. lower) levels of the magma chamber.

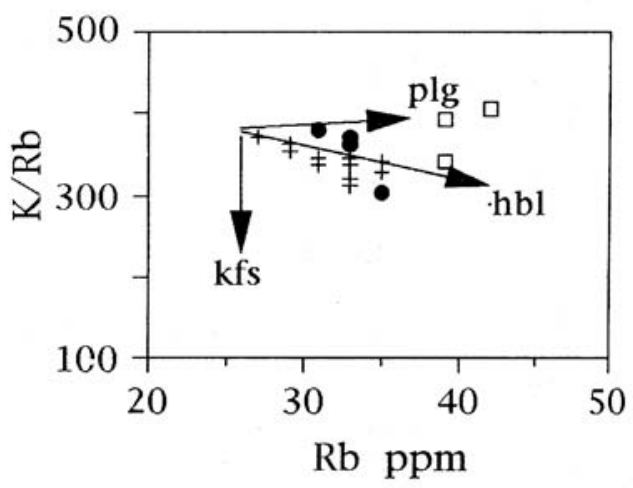

Fig. 6: Fractionation vectors. Symbols as in Fig. 4.

\section{B1 Unit:}

Pumice belonging to B1 unit are lightgrey to grey, they do not show a substantial difference in porphyricity and in the degree of vesiculation respect to the Basal Fall unit. 
Table 2.

${ }^{39} \mathrm{Ar} / 40 \mathrm{Ar}$ results.

Data were obtained on groundmass separates of lavas.

\begin{tabular}{lcccccccc}
\hline Sample & Group & $\begin{array}{c}\text { Plateau age } \\
(\mathrm{Ma})\end{array}$ & $\begin{array}{c}\text { Integrated age } \\
(\mathrm{Ma})\end{array}$ & $\begin{array}{c}\mathrm{K} \\
(\mathrm{wt} \%)\end{array}$ & $\begin{array}{c}\mathrm{Ca} \\
(\mathrm{wt} \%)\end{array}$ & $\begin{array}{c}\mathrm{Cl} \\
(\mathrm{ppm})\end{array}$ & $\begin{array}{r}40 \mathrm{Ar} * \\
(\mathrm{pl} / \mathrm{g})\end{array}$ & Total steps \\
\hline SVN 73 & pre-caldera & $0.59 \pm 0.09$ & $0.90 \pm 0.12$ & 1.57 & 1.72 & 28 & 51.9 & 10 \\
SVN 36 & post-caldera & $0.55 \pm 0.04$ & $0.77 \pm 0.14$ & 1.96 & 1.89 & 24 & 58.5 & 11 \\
SVN 134 & post-caldera & $0.06 \pm 0.05$ & $0.15 \pm 0.13$ & 1.25 & 3.20 & 259 & 7.2 & 8 \\
\hline
\end{tabular}

Among phenocrysts plagioclase is the most abundant crystalline phase, while clinopyroxene and orthopyroxene are less abundant respect to $\mathrm{BF}$, seldom they are clustered in glomeroporphyritic. Hornblende does not occur in the B1 unit.

Unit B1 shows very smooth chemical variations. This peculiarity is probably due to tapping from a more homogeneous magma chamber.

\section{Unit:}

Further up-section, pumices of $\mathrm{C}$ unit show an abrupt decrease in porphyricity (as low as $5 \%$ ) and in the abundance of mafic minerals; conversely plagioclase is the most abundant crystalline phase while clinopyroxene is $<5 \%$ of total phenocrysts. Plagioclase often shows broken edges that could reflect crystal-shattering just before the eruption.

Chemically, unit $\mathrm{C}$ is characterized by more evolved products, probably connected to a smaller, zoned, magma chamber. Pumice inside unit $\mathrm{C}$ have a rhyolitic-rhyodacitic composition and show a vertical variation similar to that of $\mathrm{BF}$, the last erupted products being less evolved.

Major elements variations are well correlated with silica that is distinctly higher than in BF, ranging from 66 to $71 \mathrm{wt} \%$. The greater degree of evolution with respect to $\mathrm{BF}$, as already seen by the very low porphyricity, is confirmed by the lower contents of $\mathrm{V}$ (40-70 vs 95-130 ppm of BF) and mg\# (28-36 vs. 38-42 of BF). $\mathrm{K}_{2} \mathrm{O}, \mathrm{Zr}, \mathrm{Rb}$ and $\mathrm{Ba}$ are highest among the analyzed rocks, while $\mathrm{Sr}$ is lowest. These patterns coupled with the constancy of $\mathrm{MgO}$ and $\mathrm{CaO}$ and the increase of $\mathrm{K} / \mathrm{Rb}$ ratio vs. silica, reflect the importance of plagioclase fractionation and the subordinate role of hornblende and clinopyroxene.

The triggering mechanism remains still uncertain. Magma mixing is ruled out by (i) the lack of juvenile mafic fragments and (ii) by the lack of an abrupt increase of compatible elements in intermediate liquids.

\section{GEOCHRONOLOGY}

Groundmass separates from one pre-caldera lava and two post-caldera lavas were used for ${ }^{39} \mathrm{Ar} / 40 \mathrm{Ar}$ dating in order to constrain the onset of the pyroclastic eruption. Previous K/Ar ages on two pre-caldera whole-rock samples gave an agespan of 2.2 to $1.2 \mathrm{Ma}$ (Rotolo et al., 1988). Results are shown in Table 2 and Figs. 10-12. The plateau age was calculated using the weighted means of adjacent steps which agree within $2 \sigma$.

(1) Pre-caldera sample SVN 73 (groundmass) shows considerable complexity. The release pattern shows that there was a major contribution from a low $\mathrm{Ca} / \mathrm{K}$ phase $(\mathrm{Ca} / \mathrm{K}$ $\leq 1)$ thought to be the K-rich groundmass. The $\mathrm{Ca} / \mathrm{K}$ increase with temperature (Fig. 7b) reflects the increasing contribution of Ca-plagioclase and/or clinopyroxene. Its age spectrum (Fig. 7a) does not yield a plateau, but rather a saddle-shaped age spectrum diagnostic of excess Ar. In this case the age is best approximated by the step with the lowest age, $0.59 \pm 0.09 \mathrm{Ma}$. An isochron diagram (not shown) failed to 
give reliable results, because the calculated $40 \mathrm{Ar} / 36 \mathrm{Ar}$ ratio would be lower than that of the atmosphere. This artefact is certainly due to the fact that the analysed groundmass is a mixture of different minerals, each of which can have trapped a different proportion of excess Ar.

(2) Post-caldera sample SVN 36 (groundmass) shows a plateau spanning $\approx 90 \%$ of the Ar release (Fig. 8a). The plateau age is $0.55 \pm 0.04 \mathrm{Ma}$.

The post-caldera sample SVN 134 (Fig. $9 \mathrm{a}, 9 \mathrm{~b})$ released the highest amount of $39 \mathrm{Ar}(60$

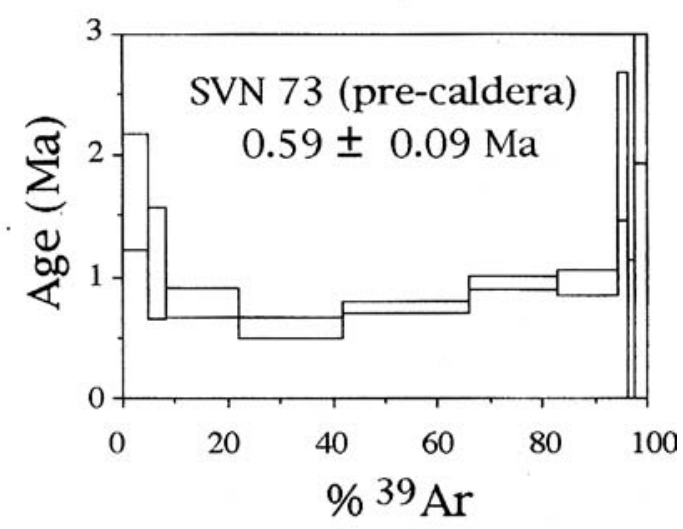

Fig. 7: a) Age spectrum of sample SVN 73;

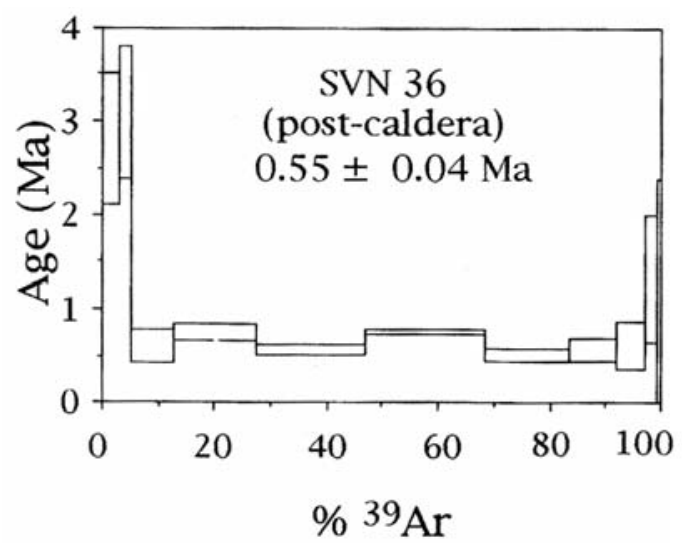

Fig. 8: a) Age spectrum of sample SVN 36;
$\%)$ at low temperature $\left(400{ }^{\circ} \mathrm{C}\right)$. The corresponding age (64 $\pm 48 \mathrm{ka})$ probably dates very finegrained alteration phases. The presence of $\mathrm{Cl}$ rich alteration is supported by the high $\mathrm{Cl}$ contents in the low temperature steps, about 40 times higher than the corresponding steps of SVN 36 and SVN 73.

The time-bracket during which the caldera event occurred is thus rather small, $40 \pm 96$ ka. It is possible that the regional stress distribution around $0.55-0.59 \mathrm{Ma}$ favoured an eruptive climax, leading to the eruption of a considerable amount of lavas and ignimbrites in less than 0.1 Ma.

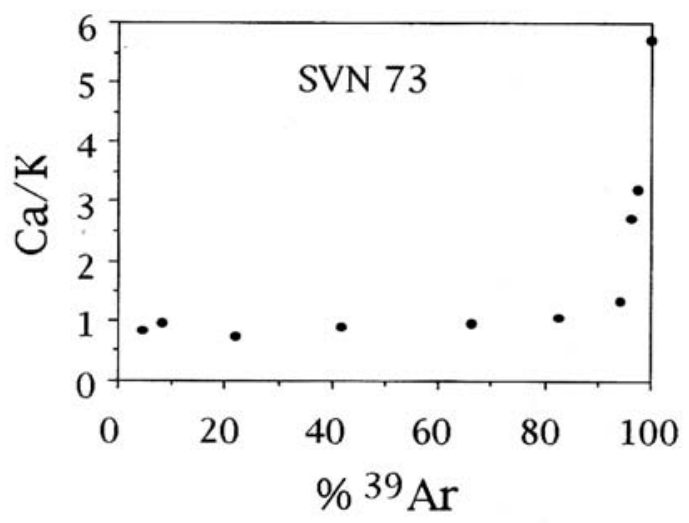

b) corresponding $\mathrm{Ca} / \mathrm{K}$ ratios.

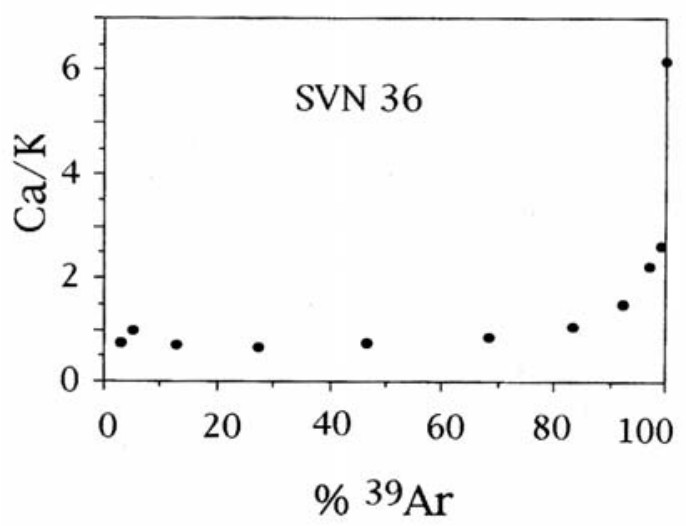

b) corresponding $\mathrm{Ca} / \mathrm{K}$ ratios. 


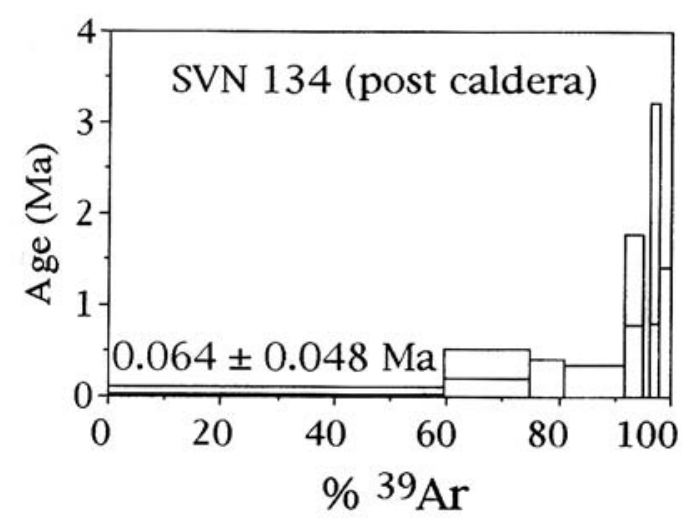

Fig. 9: a) Age spectrum of sample SVN 134;

\section{CONCLUSIONS}

The pyroclastic sequence that crops out at Chichontepeque volcano is interposed between pre-caldera tholeiitic-transitional lavas and post-caldera calc-alkaline lavas. It was produced during the Plinian phases that marked the end of pre-caldera effusive activity and determined the partial collapse of the edifice itself. It is composed of three units separated by welldeveloped paleosols.

Distribution patterns of pumice-fall horizons indicate that the eruptive vent, now buried by the most recent andesitic lava flows, could be located inside the La Carbonera caldera. Chemical trends show initially (i.e. in the Basal Fall) an evolution driven by the tapping of progressively lower levels in the magma chamber; hornblende removal is likely to be responsible of the main evolutive trend. The second fall unit (B1) shows only small chemical variation, which means that an already well-homogeneized chamber or a single homogeneous volume was tapped.

The higher fall unit (C), deposited during a subsequent Plinian phase, shows a higher degree of evolution; this could be interpreted as due to the tapping from a more evolute level of the magma chamber, after a quiescence period that allowed the development of convective gradients inside the chamber itself.

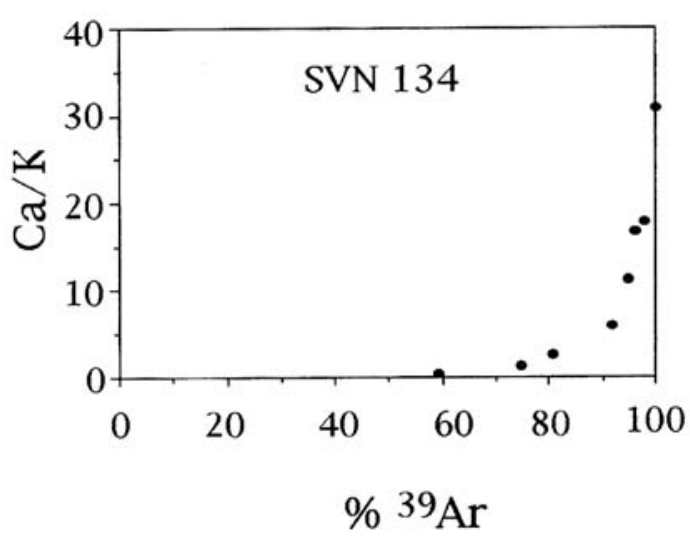

b) corresponding $\mathrm{Ca} / \mathrm{K}$ ratios.

${ }^{39} \mathrm{Ar} / 40 \mathrm{Ar}$ dating allowed us to constrain the beginning of the Plinian phase. It is bracketed by the age of a pre-caldera lava $(\leq 0.59 \pm 0.09 \mathrm{Ma})$ and a post-caldera lava $(0.55 \pm 0.04 \mathrm{Ma})$.

\section{ACKNOWLEDGMENTS}

The Salvadorian State Agency for Electric Power, Comision Ejecutiva Hidroelectrica del Rio Lempa (CEL) is warmly thanked for the valuable cooperation and assistance with logistical support during field work in El Salvador. A special thank is due to Dr. C. Pullinger for many helpful suggestions.

We would also sincerely like to thank Dr. A. Bertagnini and Dr. P. Landi (University of Pisa) for their helpful comments and constructive criticism on an early version of this paper. We would like also to thank the official reviewers and Dr. S. Kussmaul for the editorial comments.

\section{REFERENCES}

AIUPPA, A., CARAPEZZA, M.L. \& PARELLO, F., 1997: Fluid geochemistry of the San Vicente geothermal field (El Salvador). Geothermics, 26: 83-97. 
BARBERI, F., ROTOLO, S.G. \& AIUPPA, A., 1995: Petrology of Chichontepeque volcano (El Salvador). - Per Mineral., 64: 89-91.

CARR M.J. 1976: Underthrusting and Quaternary faulting in northern Central America. Geol. Soc. Am. Bull. 87: 825-829.

CARR, M.J. \& STOIBER, R.E., 1977: Geologic setting of some destructive earthquakes in Central America. - Geol. Soc.Am. Bull., $88: 151-156$.

CARR, M.J., MAYFIELD, D.G. \& WALKER, J.A., 1981: Relation of lava compositions to volcano size and structure in $\mathrm{El}$ Salvador. Jour. Volc. Geoth. Res. 10: 35-48.

FRANZINI, M., LEONI, L. \& SAITTA M., 1975: Revisione di una metodologia analitica per fluorescenza $\mathrm{X}$ basata sulla correzione completa degli effetti matrice. - Rend. Soc. It. Mineral. Petrol., 31 : 365-378.

HART, W.J.E. \& STEEN-MCINTYRE, V., 1983: Tierra Blanca Joven tephra from the A.D. 260 eruption of Ilopango. In The Zapotitn Valley of El Salvador. - Archaeology and Volcanism in Central America. Ed. Payson D. Sheets. pp. 14-43. University of Texas Press. Austin.
INMAN, D.L., 1952: Measures of describing the size distribution of the sediment. -Jour. Sed. Petrol., 22: 125-145.

PICHLER, H. \& WEYL, R., 1973: Petrochemical aspects of Central American magmatism. Geol. Rundschau 62 : 357-396.

ROTOLO, S.G. \& CASTORINAF., 1998: Transition from mildly-tholeiitic to a calcalkaline suite: the case of Chichontepec volcanic center, El Salvador, Central America. -Jour. Volcanol. Geotherm. Res. 86/1: 117-136.

ROTOLO, S.G., AIUPPA, A., PULLINGER, C.R., PARELLO, F. \& TENORIO-MEJIA J., 1998: An introduction to the San Vicente Volcano, El Salvador. -Rev. Geol. Amer. Central: 21 : 25-36.

WALKER, G.P.L., 1971: Grain-size characteristics of pyroclastic deposit. -Jour. Geol., 79: 696-714.

WIESEMANN G., 1975: Remarks on the geologic structure of the republic of $\mathrm{El}$ Salvador, Central America. - Mitt. Geol. Paleontol. Inst. Univ. Hamburg, 44 : 557-574.

WILLIAMS, H. \& MEYER-ABICH, H., 1955: Volcanism in the southern part of El Salvador. - Univ. Calif. Publ. Geol. Sci. 32 : 1-64 Berkeley and Los Angeles. 